\title{
Coral mucus as an efficient trap for picoplanktonic cyanobacteria: implications for pelagic-benthic coupling in the reef ecosystem
}

\author{
Malik S. Naumann ${ }^{1, *}$, Claudio Richter ${ }^{2}$, Mohammad el-Zibdah ${ }^{3}$, Christian Wild ${ }^{1}$ \\ ${ }^{1}$ Coral Reef Ecology Work Group (CORE), GeoBio-Center \& Department of Earth and Environmental Science, \\ Ludwig-Maximilians-Universität München, Richard-Wagner-Str. 10, 80333 München, Germany \\ ${ }^{2}$ Alfred Wegener Institute for Polar and Marine Research, PO Box 120161, 27515 Bremerhaven, Germany \\ ${ }^{3}$ Marine Science Station, University of Jordan and Yarmouk University, PO Box 195, Aqaba, Jordan
}

\begin{abstract}
Although the planktonic community of coral reefs is dominated by picoplankton (e.g. the cyanobacterium Synechococcus), it was long believed to play only a marginal role in pelagicbenthic coupling, as its minute size $(0.2$ to $2.0 \mu \mathrm{m})$ and negligible sinking rate render it largely unavailable for the filter-feeding reef benthos. However, scleractinian corals have been shown to continuously release mucus that functions as an efficient trap and important carrier for particulate matter within the reef ecosystem. This study investigates the trapping potential of coral mucus for picoplankton in the laboratory and in the field. Freshly released mucus of Fungia corals already contained background levels of pelagic and/or associated synechococcoid cyanobacteria $(1.0 \pm 0.2 \times$ $10^{4} \mathrm{cells} \mathrm{ml}^{-1}$ ). Mesocosm experiments in flow-through tanks revealed up to 46-fold picoplankton enrichment in aged mucus aggregates, while laboratory experiments with rotated chambers confirmed the pelagic source of these mucus enrichments. Addition of coral mucus resulted in a significant increase in clearance rates $\left(32\right.$ to $\left.52 \% \mathrm{~h}^{-1}\right)$ of the initial Synechococcus spp. population compared to clearance found in non-mucus chambers $\left(6\right.$ to $\left.18 \% \mathrm{~h}^{-1}\right)$. Drifting mucus aggregates originating from Acropora corals collected in situ exhibited high Synechococcus enrichment (up to $\left.4.6 \times 10^{6} \mathrm{cells} \mathrm{ml}^{-1}\right)$ compared to the surrounding seawater $\left(2.1 \pm 0.8 \times 10^{4}\right.$ cells ml $\left.{ }^{-1}\right)$, indicating efficient picoplankton enrichment by 2 orders of magnitude. The ensuing rapid sedimentation $(0.5$ to $1 \mathrm{~cm} \mathrm{~s}^{-1}$ ) of enriched aggregates highlights the importance of coral mucus as a so far overlooked vector enhancing the flux of pelagic picoplankton to the coral reef benthos.
\end{abstract}

KEY WORDS: Coral mucus · Picoplankton $\cdot$ Aggregates $\cdot$ Synechococcus $\cdot$ Pelagic-benthic coupling Red Sea

Resale or republication not permitted without written consent of the publisher

\section{INTRODUCTION}

Most of the world's pelagic ocean regimes are dominated by unicellular picoplankton organisms $(0.2$ to $2.0 \mu \mathrm{m}$ cell size) (Sieburth et al. 1978) known to constitute a substantial fraction of planktonic biomass and primary production (Li et al. 1983, Owens et al. 1993, Tremblay \& Legendre 1994). Oligotrophic waters around coral reefs are characterised by a picoplankton community principally composed of phototrophic cyanobacteria, heterotrophic bacteria and a diverse group of picoeukaryotes (Ribes et al. 2003). Of these, heterotrophic bacteria generally dominate by 1 order of magnitude in terms of cell abundance (Weisse 1989, Gradinger et al. 1992, Ribes et al. 2003), while unicellular cyanobacteria dominate picoplankton biomass (Ducklow 1990). In Red Sea waters, picoplanktonic cyanobacteria (Synechococcus and Prochlorococcus, Johnson \& Sieburth 1979) represent $69 \%$ of planktonic chlorophyll a (chl a) and $77 \%$ of planktonic primary production (Pillen \& Moigis, cited in Lenz et al. 1988), reaching maximum abundances in the range of $2.6 \times$ 
$10^{5}$ Synechococcus cells $\mathrm{ml}^{-1}$ during bloom seasons (Lindell \& Post 1995). In spite of the widely recognised importance of picoplankton within marine ecosystems as biomass pool and energy source, the role of picoplankton in coral reef pelagic-benthic coupling is so far little understood. Due to their minute size, picoplankton cells contribute little to the vertical particle flux (Pedros-Alio et al. 1989, Richardson \& Jackson 2007) and thus remain largely inaccessible to the benthos. Although active suspension feeders (e.g. sponges) are known to thrive on this minute particulate food (Richter et al. 2001), there is growing evidence also that passive suspension feeders such as scleractinian (Ribes et al. 2003, Houlbrèque et al. 2004) and soft corals (Fabricius et al. 1995) are able to tap the stream of picoplankton across the reef - yet a plausible mechanistic explanation for picoplankton uptake by passive suspension feeders is still wanting. Significant removal of picoplankton from water flowing across coral reefs has been reported in several studies (Ayukai 1995, Ribes et al. 2003, Houlbrèque et al. 2006). Ayukai (1995) suggested that in this context the observed decrease in picoplankton might partially be affected by aggregate forming transparent exopolymers (i.e. mucoid exudates) released by the benthic reef community. Several benthic reef species are known to utilize mucoid exudates for feeding purposes, e.g. the vermetid gastropod Dendropoma maxima (Kappner et al. 2000) or the scleractinian coral Mycetophyllis reesi (Goldberg 2002). Mucoid exudates of scleractinian corals and their aged particle-enriched aggregation stages represent a potential trophic- and nutrient-recycling pathway in coral reef ecosystems acting as efficient traps and aggregation media for suspended particulate matter, including small plankton organisms (Johannes 1967, Wild et al. 2004a,b, 2005a). However, microscopic investigations concerning particle enrichment of coral mucus aggregates carried out thus far disregarded the possible enrichment with entrapped picoplankton. Other authors have reported on the entrapment of picoplankton-sized particles and cells into organic aggregates, followed by a rapid vertical transport to greater depth (Noji et al. 1997). Organic aggregates sampled from $120 \mathrm{~m}$ depth within the Subtropical Front off New Zealand show high contents of embedded picophytoplankton and high vertical mass fluxes to this depth (Waite et al. 2000). As shown for deep epipelagic environments, entrapment of picoplankton and subsequent vertical transport of picoplankton-enriched coral mucus aggregates may represent a potential trophodynamic pathway linking the picoplankton-rich pelagic compartment to the benthos in shallow reef ecosystems.

The goal of this study was to investigate the potential of scleractinian coral mucus to act as an efficient trap for picoplankton, thus forming picoplankton-enriched mucus aggregates enhancing the availability of this otherwise elusive biomass for reef dwelling organisms. For this purpose, trapping efficiency of, and picoplankton enrichment in, coral mucus aggregates was tested in 3 different experimental approaches (rotated chamber incubations, mesocosm experiments and in situ samplings of coral mucus aggregates) utilising the picoplanktonic cyanobacterium Synechococcus as a representative of picoplankton.

\section{MATERIALS AND METHODS}

Study site. The present study was conducted at the Marine Science Station Aqaba, Jordan $\left(29^{\circ} 27^{\prime} \mathrm{N}\right.$, $\left.34^{\circ} 58^{\prime} \mathrm{E}\right)$, situated approximately $10 \mathrm{~km}$ south of the city of Aqaba with exclusive access to a marine reserve featuring a typical Red Sea fringing reef. All laboratory and field work was carried out in local facilities and adjacent reef sites in the study period October 2004 until March 2005.

Coral samples. Individuals of the solitary mushroom coral Fungia ( $\mathrm{n}=21$ ) were collected over several days from 4 different locations within the fore reef in 5 to $10 \mathrm{~m}$ depth. The coral polyps were transported to the laboratory and kept in $1000 \mathrm{l}$ flow-through tanks with a constant supply of fresh seawater at in situ temperature $\left(21\right.$ to $22^{\circ} \mathrm{C}$ ) and salinity (41 to 43$)$. Fungia polyps were selected because of their high abundance and strong mucus production, as observed in a previous study (Wild et al. 2005b). Additionally, as Fungia polyps are free-living, they can be removed and returned to the reef without any mechanical damage to the coral and the surrounding environment. The skeleton surface area of all corals was quantified applying a geometric approximation protocol in combination with a specific approximation factor (AF) for Fungia corals, derived from comparative analysis with a computer tomography-based surface area measurement technique (Naumann et al. 2009). Briefly, each Fungia polyp was considered as a disc composed of 2 circular sides and a rectangular side. The average disc radius was calculated from the measured maximum and minimum horizontal polyp diameters. From this, the oral and aboral polyp surface areas were calculated as circles. The surface area of the rectangular side was calculated from measurements of the disc height and perimeter, and finally added to gain the total surface area of the disc. Subsequently, the geometrically assessed surface area was multiplied with the AF to improve accuracy.

Rotated chamber incubations. Cultivation of picoplankton: Clonal cultures of Synechococcus strain RS9909, isolated from the Northern Red Sea by Fuller et al. (2003), were obtained through the Roscoff Cul- 
ture Collection, France. Cultures were grown in liquid ASN III+ medium, which had been adjusted to local surface seawater salinity values (42). Cultivation was carried out in $100 \mathrm{ml}$ Erlenmeyer flasks at a constant temperature of $21^{\circ} \mathrm{C}$ and light intensity of approximately $50 \mu \mathrm{mol} \mathrm{m}{ }^{-2} \mathrm{~s}^{-1}$ (12:12 h light:dark cycle).

Coral mucus collection: Mucus collection was carried out according to the technique described in Wild et al. (2005b). Fungia polyps were exposed to air, and the disk-like coral polyps were held vertically. Mucus release started immediately and was observed by long gel-like mucus threads dripping from the coral surface. The first $30 \mathrm{~s}$ of mucus production were discarded to prevent contamination and dilution through seawater. Subsequently, the released mucus (volumes: 2 to $25 \mathrm{ml}$ ) was collected for $2 \mathrm{~min}$ in a clean glass dish and processed immediately or stored at $4^{\circ} \mathrm{C}$ in a sealed glass container until further use. The abundance of synechococcoid cyanobacteria (Synechococcus, but possibly also coral-associated cyanobacteria; cf. Lesser et al. 2007) in freshly released coral mucus served as a reference to calculate the mucoidal entrapment rates of Synechococcus in subsequent experiments. Preliminary research revealed that the volume of mucus released by Fungia polyps after $30 \mathrm{~s}$ of air exposure was variable and showed a positive correlation to polyp surface area $\left(\mathrm{r}^{2}=0.869, \mathrm{M}\right.$. S. Naumann unpubl. data). Considering this, and to additionally account for polyp-specific variability, possibly caused by differing life histories, 4 random replicates from 4 differently sized Fungia polyps (surface areas: 132, 178, 228 and $294 \mathrm{~cm}^{2}$ ) and reef locations were selected. Abundance of synechococcoid cyanobacteria was assessed in $1 \mathrm{ml}$ aliquots of freshly released mucus using epifluorescence microscopy (EFM) as described below.

Rotated chamber incubations: To investigate trapping efficiency of coral mucus for natural as well as for a cultured (RS9909) Synechococcus strain, independent triplicate rotated chamber experiments (hereafter: I, II, and III) were carried out. To discriminate between the contribution of coral mucus and other possible factors influencing Synechococcus clearance, chamber incubations with different control characteristics were run in parallel. Acid-washed cylindrical transparent acrylic chambers $(\mathrm{C} 1$ to $\mathrm{C} 5$, diameter $=$ $11.5 \mathrm{~cm}$, height $=11.5 \mathrm{~cm}$ ) were filled with freshly collected seawater and chamber-specific additives (see also Fig. 1), to a final volume of $555 \mathrm{ml}$ (headspace $\approx$ $445 \mathrm{ml}$ air). All chambers contained fresh Red Sea seawater including natural Synechococcus strains (mean abundance $\approx 2.6 \times 10^{4}$ cells ml ${ }^{-1}$ ). Chamber $\mathrm{C} 1$ always contained untreated seawater with natural concentrations of Synechococcus. Chamber C2 was additionally spiked with Synechococcus strain RS9909 (mean abundance $\approx 2.1 \times 10^{5}$ cells ml ${ }^{-1}$, corresponding to Syne- chococcus concentrations during the bloom season, Lindell \& Post 1995). Chambers C3 and C4 contained natural and spiked concentrations of Synechococcus, respectively, with freshly collected Fungia mucus (15 ml for Expt I and $50 \mathrm{ml}$ for Expts II and III). Chambers $\mathrm{C} 1$ through $\mathrm{C} 4$ were placed on a roller table apparatus as described in Shanks \& Edmondson (1989) and rotated for $1 \mathrm{~h}$ at a constant rotation velocity of 2 (Expt I) or 1 (Expts II and III) $\mathrm{cm} \mathrm{s}^{-1}$ (equivalent to $\sim 3$ or $1.5 \mathrm{rpm}$, respectively). Chambers C1 and C2 were used to account for clearance caused by rotation-induced cell aggregations and grazing. As all chamber incubations were carried out under dimmed light intensity $\left(\sim 5 \mu \mathrm{mol} \mathrm{m} \mathrm{m}^{-2} \mathrm{~s}^{-1}\right)$, picoplankton growth was regarded as negligible within the short experimental duration and cell aggregation caused by intense illumination (Koblizek et al. 2000) could be ruled out. Chambers C3 and $\mathrm{C} 4$, combining all possible factors for picoplankton clearance, served to identify the contribution of mucus trapping to picoplankton clearance by consideration of all other factors observed in parallel-run chambers. The increased Synechococcus concentration in C4 was used to investigate mucus trapping and enrichment at elevated picoplankton abundances, i.e. during bloom season. Chamber $\mathrm{C} 5$, treated the same as $\mathrm{C} 4$, was placed without rotation next to the roller table (equal temperature and light conditions) as a control for rotation independent picoplankton clearance processes (cell aggregation, mucus trapping and grazing on Synechococcus).

Mucus volume added was converted to particulate organic carbon (POC) using POC contents of Fungia mucus (M. S. Naumann unpubl. data), mucus dissolution ratios (Wild et al. 2004a) and in situ POC concentrations during the study period (92 to $279 \mathrm{mg} \mathrm{l}^{-1}$; M. Naumann unpubl. data), leading to corresponding values of 81 and $269 \mathrm{mg} \mathrm{Cl}^{-1}$ for 15 and $50 \mathrm{ml}$ mucus added, respectively. The latter value was equivalent to a doubling of the POC concentrations in chambers C3 to C5.

Synechococcus clearance was assessed by measurements of cell abundance at initial conditions (before chamber rotation) and after $1 \mathrm{~h}$ of continuous rotation in all chambers of the independent replicate experiments $(\mathrm{n}=3)$. Chambers $\mathrm{C} 1$ through $\mathrm{C} 5$ were placed on a table and left undisturbed for $5 \mathrm{~min}$. After this preliminary settling period, one $10 \mathrm{ml}$ sample was drawn from the uppermost surface water of each container using sterile syringes and transferred into a $15 \mathrm{ml}$ settling vial (height $=13 \mathrm{~cm}$ ). To each settling vial, $1 \mathrm{ml}$ of a fixative solution (final concentration $=0.1 \%$ paraformaldehyde and $0.05 \%$ glutaraldehyde), as described in Marie et al. (2000), was added to inhibit cell growth and to ensure preservation of Synechococcus accessory pigments (i.e. phycoerythrins, chlorophylls) for later EFM analyses. Subsequently, the set- 
tling vials were left for a $48 \mathrm{~h}$ sedimentation period in the dark, leading to a separation of cells between the suspended (homogenous distribution, no gravitational settling) and aggregated fraction (gravitational settling) with time. After the separation period, a $4 \mathrm{ml}$ sample was taken from the upper surface water of each settling vial. Synechococcus abundance was quantified in these solutions using EFM in the way described below. Samples from rotated chambers C2 and C4, and non-rotated chamber C5 were investigated for cell abundance of cultured Synechococcus strain RS9909, while C1 and C3 samples were checked for cell abundance of natural Synechococcus strains.

Mesocosm experiments. Trapping efficiency of coral mucus for natural strains of Synechococcus was examined by 6 independent identical experiments in a 501 flow-through aquarium flushed with seawater freshly pumped from the reef. Each experiment was conducted during 1 daylight period and involved the incubation of 2 to 5 Fungia polyps (total: $\mathrm{n}=21$ ). Water temperature, measured by using mercury thermometers, was constant during all conducted experiments (21 to $22^{\circ} \mathrm{C}$ ) and salinity, measured with a handheld refractometer, ranged between 41 and 43. Water flowthrough rates were 1.8 to $4.21 \mathrm{~min}^{-1}$, as derived by quantification of aquarium outflow. Fungia polyps were briefly air-exposed (5 s) to initiate enhanced mucus production and thereafter placed on the bottom of the aquarium filled with fresh seawater. Air exposure, as a natural incident for scleractinian corals in the study area (Loya 1976), was used to generate a distinct starting point for Synechococcus trapping by coral mucus that was subsequently included in the calculation of exposure periods for mucus aggregates and finally applied in calculations of Synechococcus trapping rates. The aquarium inflow was directed horizontally at half aquarium height creating a unidirectional flow of ca. $4 \mathrm{~cm} \mathrm{~s}^{-1}$ (comparable to in situ conditions), as derived from visual tracing of particles over the coral surface. The water stream carried air bubbles of various size classes, simulating conditions identical to those observed in the natural shallow reef environment. Fungia polyps exuded mucus that formed webs drifting in the water stream, thereby becoming continuously enriched with air bubbles and suspended particulate matter. These mucus webs were subsequently compacted to mucus strings by the water stream and finally ascended to the water surface, where they accumulated to mucus floats. As the substantial part of particle trapping took place during mucus web and mucus string formation periods (Wild et al. 2004a, 2005b), the transition from 3-dimensional string morphology to 2-dimensional float morphology consequently represented the end point of effective mucus particle trapping.
After 30 or 60 min of incubation, mucus float accumulation was sufficient for quantitative sampling and a sample was taken by syringe from the aggregated mucus float at the water surface. Sampling was carried out by establishing contact between the opening of the syringe tip and the mucus float to initiate suction of the sample. Shortly after, the syringe was lifted approximately $2 \mathrm{~cm}$ up from the water surface, while suction of the sample was continued, taking advantage of cohesion strength and viscosity of the mucus float material. By this gravitational separation procedure, sample contamination/dilution by Synechococcus from ambient seawater was minimised. Dilution ratio was approximately 100:1 (mucus float sample:seawater). Immediately after suction, the sample volume was measured using the syringe volume scale, and mucus floats were stored in the dark at $4^{\circ} \mathrm{C}$ until further processing no later than $6 \mathrm{~h}$ after sampling. Seawater samples (100 ml, $\mathrm{n}=3$ ) were taken between individual coral incubations within each experiment to determine ambient versus mucus aggregate abundances of Synechococcus. Mucus float (5 to $10 \mathrm{ml}$ ) and seawater samples $(100 \mathrm{ml})$ were filtered and analysed by EFM as described below. EFM results were related to the initially measured volume of sample material, avoiding bias caused by thermal mucus volume compaction during storage $\left(4^{\circ} \mathrm{C}\right)$, and expressed as Synechococcus cells $\mathrm{ml}^{-1}$ mucus float or seawater. To account for possible bias due to synechococcoid cyanobacteria already present in freshly released Fungia mucus (i.e. to provide trapping rates on a 'per volume of freshly released mucus' basis) we subtracted these concentrations from Synechococcus concentrations in mucus floats in the calculation of Synechococcus trapping rates.

To correct for possible bias by mucus volume compaction and mucus dissolution during incubations, compaction factors (CFs) were generated 3-fold for each experiment. For this purpose, a syringe was filled with $100 \mathrm{ml}$ of fresh gel-like mucus and subsequently used to spread this mucus onto the skeleton surface of a dead Fungia polyp placed in the flowthrough aquarium. A dead clean Fungia skeleton was used as a substitute simulating morphological features of a living Fungia polyp, thus providing the mucus with a substrate, allowing for similar mucus aggregate formation and compaction conditions. After an incubation period of 30 and $60 \mathrm{~min}$, respectively, CFs were determined, as defined by the relation between the volume of detectable mucus float and the volume of the initially introduced mucus. To correct for the dissolution of fresh gel-like mucus in seawater, the initial volume of introduced gel-like mucus was corrected by a dissolution factor of 0.32 (Wild et al. 2004a). 
In situ sampling of coral mucus aggregates. Mucus aggregates were sampled from the water column in close vicinity to the reef crest to explore the trapping efficiency of coral mucus for Synechococcus under in situ conditions. At each of 4 sampling events (comparable environmental conditions; summary given in Table 1), coral colonies of the genus Acropora growing in 0.5 to $1.0 \mathrm{~m}$ water depth were visually inspected for attached mucus strings using SCUBA. Mucus strings originating from 5 to 10 coral colonies were collected separately, after final detachment from the coral and drifting through the water column for 8 to $15 \mathrm{~min}$, using $10 \mathrm{ml}$ syringes (total: 27 string samples). Inside sampling syringes, mucus string samples were clearly distinguishable from supernatant seawater, introduced during sampling, by entrapped particulate matter inducing gravitational settlement of the strings. Separation of mucus string material from supernatant seawater was carried out to avoid spurious increases of Synechococcus in the mucus string material. This was accomplished by holding the sampling syringe vertically (opening pointing upward) and draining the supernatant seawater to a ratio of 100:1 (mucus string:seawater). After elimination of seawater, the volume of the sampled mucus strings was measured inside the sampling syringe using the volume scale, before strings were filtered for subsequent EFM analysis. At each sampling event, triplicate seawater samples $(100 \mathrm{ml})$ were taken in the vicinity of the reef crest to determine ambient Synechococcus abundance. Further processing of mucus string samples and determination of Synechococcus abundance in strings and seawater was carried out using EFM as described below. The EFM-resulting Synechococcus abundance in mucus strings and seawater was related to the volume of the filtered material and expressed as Synechococcus cells $\mathrm{ml}^{-1}$ mucus string or seawater.

Microscopic analysis. Mucus aggregate samples were diluted with $0.2 \mu \mathrm{m}$ filtered seawater and homogenized in the sample vial by vigorous shaking for 1 min. A hand tissue grinder (100 strokes per sample) was used to further disintegrate aggregates, followed by another $1 \mathrm{~min}$ of vigorous shaking. Preliminary research indicated no substantial Synechococcus cell loss following this procedure. Samples from all experiments to be analysed by EFM were filtered onto black polycarbonate membrane filters (Millipore ${ }^{\mathrm{TM}}$ Isopore GTBP, $0.2 \mu \mathrm{m}$ pore size) using a vacuum of not more than $100 \mathrm{~mm}$ of $\mathrm{Hg}$ (Passow \& Alldredge 1995). To achieve random distribution of cells, filters were soaked in deionised water before use (Crumpton 1987) and sucked dry after placing on the filtration unit. A membrane filter (Millipore ${ }^{\mathrm{TM}} \mathrm{HA}_{;} 0.4 \mu \mathrm{m}$ pore-size) was used as a backing filter. Filtered samples were either examined within $1 \mathrm{~h}$ by EFM for Synechococcus abundance or stored at $-20^{\circ} \mathrm{C}$ in the dark for later analysis. Samples were examined for Synechococcus autofluorescence of phycoerythrin using a standard Zeiss $^{\mathrm{TM}}$ epifluorescence microscope (Axioskop 2) equipped with a HBO $100 \mathrm{~W}$ mercury vapour lamp and Zeiss $^{\mathrm{TM}}$ fluorescence filter sets (488015 and 488009). More than 100 cells from randomly selected fields (ocular grid: $100 \times 100 \mu \mathrm{m}$ ) were counted in the dark from each filter (Li \& Wood 1988) at 1000× magnification using a Zeiss ${ }^{\mathrm{TM}}$ Plan-Neofluar $100 \times$ objective in combination with a $10 \times$ ocular. Synechococcus strain RS9909 cells were detected by their bright red fluorescence following green light excitation (filter set: 488015) and by orange-red fluorescence after blue light excitation (filter set: 488009) (Booth 1987). Natural strains showed a bright yellow light emission after blue excitation and fluoresced orange-red at green excitation wavelengths. Additionally, for Synechococcus strain RS9909, the more elongated coccoid cell shape was used for identification, as all natural strains in contemporary seawater samples showed spherical coccoid cell morphology. Abundance of Synechococcus in clusters formed by mucus scavenging was determined by scanning of the whole filter area (at 100×) and counting of all cells inside clusters (at 1000x). Cell contents of clusters were added quantitatively and related to the filtered sample volume.

Table 1. Environmental conditions and sedimentation rates during in situ mucus sampling events. Temp: temperature; Bft: Beaufort; NA: not available

\begin{tabular}{|c|c|c|c|c|c|c|c|c|}
\hline Date & $\begin{array}{l}\text { Temp } \\
\left({ }^{\circ} \mathrm{C}\right)\end{array}$ & $\begin{array}{l}\text { Wind } \\
\text { (Bft) }\end{array}$ & $\begin{array}{l}\text { Current } \\
\left(\mathrm{cm} \mathrm{s}^{-1}\right)\end{array}$ & Cloud cover & $\begin{array}{c}\text { Sampling } \\
\text { water depth }(\mathrm{m})\end{array}$ & $\begin{array}{l}\text { Visibility } \\
\text { (m) }\end{array}$ & $\begin{array}{c}\text { Mean } \\
\text { sedimentation } \\
\text { rate }\left(\mathrm{cm} \mathrm{s}^{-1}\right)\end{array}$ & $\mathrm{n}$ \\
\hline 19 Feb 2005 & 23 & $1-2$ & NA & Clear & $0.5-2.0$ & 10 & 0.5 & 10 \\
\hline 23 Feb 2005 & 23 & 2 & 5 & Partially cloudy & $0.5-2.0$ & 10 & 0.5 & 6 \\
\hline 27 Feb 2005 & 23 & 2 & $4-5$ & Clear & $0.5-2.0$ & 12 & 0.5 & 6 \\
\hline 04 Mar 2005 & 23 & 3 & 5 & Partially cloudy & $0.5-2.0$ & 8 & 0.5 & 5 \\
\hline Total & & & & & & & & 27 \\
\hline
\end{tabular}




\section{RESULTS}

\section{Rotated chamber incubations}

The occurrence of synechococcoid cyanobacteria in freshly released Fungia mucus $\left(1.0 \pm 0.2 \times 10^{4}\right.$ cells $\mathrm{ml}^{-1}$ ) showed that pelagic Synechococcus and/or coralassociated synechococcoid cyanobacteria were consistently present in considerably constant concentrations (coefficient of variation, $\mathrm{CV}=20 \%$ ) within the corals' surface mucus layer (SML). Addition of mucus and chamber rotation (C3 and $\mathrm{C} 4$ ) resulted in the formation of mucus-particle aggregates of various size classes (diameter: $<5 \mathrm{~mm}$ to $2 \mathrm{~cm}$ ) from which the majority accumulated to 1 macroaggregate $($ diameter $=3.5 \mathrm{~cm}$ ) after $1 \mathrm{~h}$ of incubation. By contrast, no aggregate formation was observed in non-mucus (C1 and C2) and non-rotated (C5) chambers. Clearance was detectable in all chambers after $1 \mathrm{~h}$ (Fig. 1). Synechococcus clearance rates were significantly increased in rotated chambers with mucus addition (Wilcoxon signed rank test, 2-tailed, $\mathrm{p}<0.005$ ), accounting for 32 to $52 \% \mathrm{~h}^{-1}$ of the initial cell content (C3 and C4), exceeding those due to cell aggregations and/or picoplankton grazing in non-mucus and non-rotated chambers (C1, C2 and C5) by a factor of 4 (mean of Expts I, II and III) ranging only between 6 and $18 \% \mathrm{~h}^{-1}$ (Fig. 1). Taking into account clearance caused by cell aggregations and picoplankton grazing, coral mucus added to chambers C3 and C4 was responsible for 15 to $43 \%$ of Synechococcus clearance $\mathrm{h}^{-1}$. Rotation-induced cell aggregations ( $\mathrm{C} 1$ and $\mathrm{C} 2$ ) accounted for 3 to $8 \%$ clearance $\mathrm{h}^{-1}$ as calculated with consideration of results from

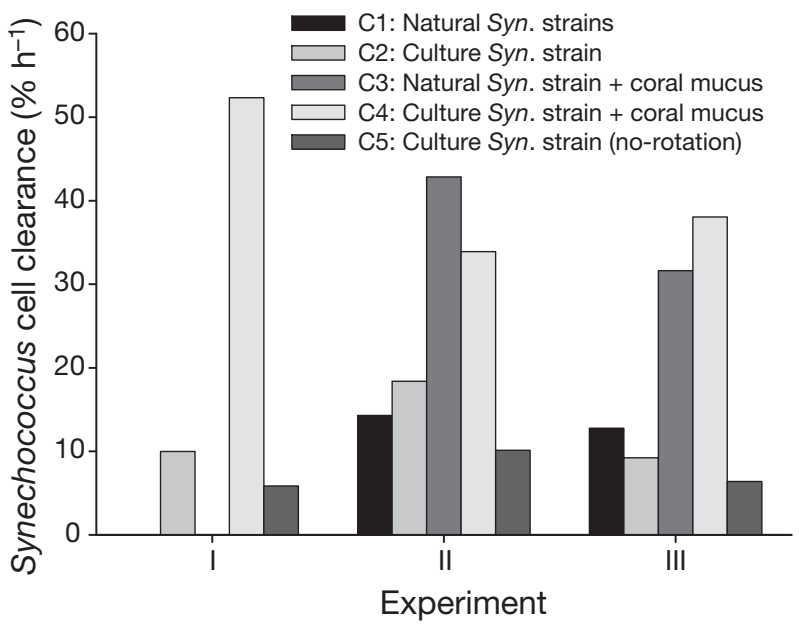

Fig. 1. Synechococcus. Clearance rates for different treatments from 3 independent rotated chamber incubations. Chambers $\mathrm{C} 1$ to $\mathrm{C} 5$ from left to right; results for $\mathrm{C} 1$ and $\mathrm{C} 3$ not available for Expt I; rotation velocity: 2 and $1 \mathrm{~cm} \mathrm{~s}^{-1}$, Expt I and Expts II and III, respectively; Syn.: Synechococcus non-rotated chamber C5 combining clearance rates caused by rotation independent cell aggregation, rotation independent mucus trapping and picoplankton grazing. No significant differences were observed in percentage clearance between $\mathrm{C} 3$ and $\mathrm{C} 4$ with regard to different initial cell abundances (1 to 2 orders of magnitude) of natural (C3) and artificially added (C4) Synechococcus strains (Expts II and III, Fig. 1). However, different initial cell abundances resulted in a significant variation in mucus trapping rates found per volume of added mucus and rotation time, constituting $2.3 \pm 1.8 \times 10^{3}$ and $1.9 \pm 0.8 \times 10^{4}$ cells ml ${ }^{-1}$ mucus min $^{-1}$ for $\mathrm{C} 3$ and $\mathrm{C} 4$, respectively (Mann and Whitney $U$-test, 2 -tailed, $\mathrm{p}<0.01$ ). In comparison of Expt I to Expts II and III, increased rotation velocity (Expt I) resulted in a higher cell clearance rate in the chamber with mucus addition (C4), in contrast to the non-mucus chamber (C2), where no velocity dependent differences were observed. Cell clearance in chamber C5 was slightly elevated in Expt II, but remained constant between Expts I and III.

\section{Mesocosm experiments}

Experiments in a large flow-through aquarium allowed for a close follow-up on the successive stages of coral mucus aggregate formation, during which extensive particle trapping occurs. Shortly (1 to $3 \mathrm{~min}$ ) after a polyp was placed in the aquarium, mucus webs of 15 to $50 \mathrm{~cm}$ length, made visible by entrapped air bubbles, were observed reaching from the coral surface into the water column. Driven by the water stream and ongoing mucus production the webs gained size and spread through the entire tank with slightly positive buoyancy. After 3 to $4 \mathrm{~min}$, the aquarium was almost entirely filled with mucus webs reaching maximum sizes of $50 \times 30 \times 20 \mathrm{~cm}$. In $90 \%$ of all replications, webs stayed attached to the coral surface forming compacted string-like structures, while the rest of the mucus web drifted through the tank unfolded. Under the influence of the water stream, mucus webs consequently compacted to mucus strings in which the amount of trapped particles (e.g. pieces of macroalgae) became visible. The increasing load of entrapped air bubbles transported mucus strings to the water surface after a mean time of $8 \mathrm{~min}$ (interval from incubation start until first detected float) forming thick mucus floats successively accumulating the ascending string material. At sampling time, a main portion of the water surface was covered with enriched mucus floats (up to $5 \mathrm{~cm}$ thick) from which mucus strings extended downwards, connecting the floats with the coral. Results from EFM analysis of mucus float material displayed significantly higher Synechococcus abundance 
(Wilcoxon signed rank test, 2-tailed, $\mathrm{p}<0.05$ ) in all mucus float samples (mean: $1.3 \pm 0.7 \times 10^{5} \mathrm{cells} \mathrm{ml}^{-1}$ ) compared to seawater samples (mean: $1.2 \pm 1.0 \times$ $10^{4}$ cells $\mathrm{ml}^{-1}$ ) on each respective experimental day, resulting in 3- to 46-fold picoplankton enrichment during the mucus aggregate-formation process (Fig. 2). Synechococcus abundance in seawater showed significant variability, within the local seasonal fluctuation range (Lindell \& Post 1995), between experimental days (1-way ANOVA, p < 0.05), but was constant in the course of each experimental day (paired-samples $t$ test, 2-tailed, p > 0.05). Synechococcus abundance in seawater was not correlated to Synechococcus enrichment found in mucus float samples on the respective experimental days (Spearman rank-order correlation, 2-tailed, p > 0.05). Trapping rates of Synechococcus per volume of fresh mucus during exposure time (8 min) accounted for $0.3 \pm 0.2 \times 10^{3}$ cells $\mathrm{ml}^{-1} \mathrm{~min}^{-1}$. Spurious enrichment of mucus floats by Synechococcus from ambient seawater could be regarded as negligible due to insignificant contribution to sample volume and significant differences in cell abundance (Wilcoxon signed rank test, 2-tailed, p < 0.05). Mucus CFs determined for the respective experiments ranged from 17 to 160 -fold.

\section{In situ sampling of coral mucus aggregates}

At all sampling events, mucus aggregates from various size classes and aging stages were abundant in the water column above the reef flat and in close seawards vicinity of the reef crest. The vast majority of Acropora colonies showed extensive mucus production in the form of mucus webs (Fig. 3a) that compacted on the coral surface and remained attached to lateral or top

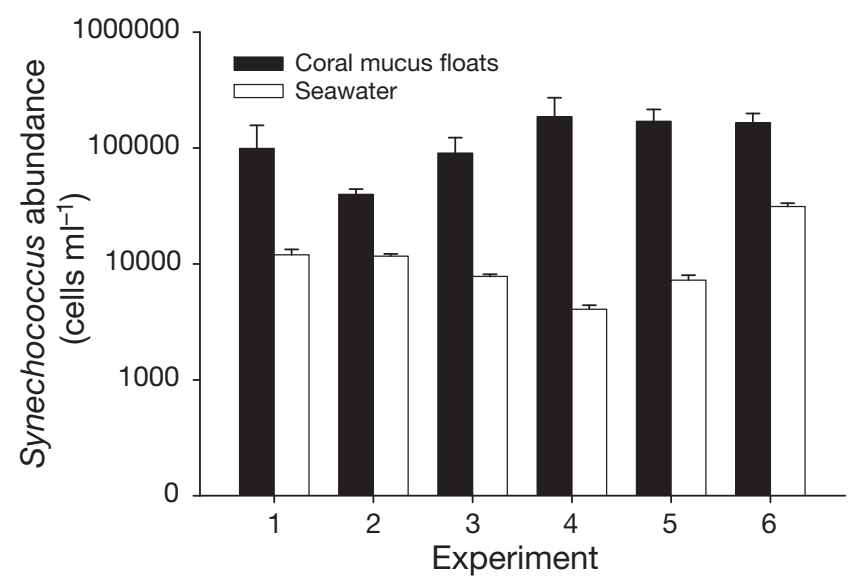

Fig. 2. Synechococcus. Abundance (mean $\pm \mathrm{SD}$ ) in coral mucus floats and seawater from mesocosm experiments. Coral mucus floats and seawater samples were collected in replicates of at least $n=3$ per experiment edges of the colonies as mucus strings (Fig. 3b,c). Strings reached lengths of between 2 and $25 \mathrm{~cm}$, and displayed positive buoyancy caused by entrapped air bubbles. Due to low current velocity ( 4 to $5 \mathrm{~cm} \mathrm{~s}^{-1}$ ), mucus strings exhibited slow compaction and remained attached to the coral for an undefined period of time. After final detachment, mucus strings drifted with neutral to positive buoyancy continuously compacting to smaller aggregates $(>1 \mathrm{~cm})$ accompanied by subsequent loss of entrapped air bubbles (Fig. 3d). Horizontal currents ( 2 to $3 \mathrm{~m} \mathrm{~min}^{-1}$ ) transported mucus strings for more than $25 \mathrm{~m}$ over deeper waters of the lower fore reef (20 to $30 \mathrm{~m}$ depth), where all strings showed negative buoyancy and descended to the seafloor with an average sedimentation velocity of $0.5 \mathrm{~cm} \mathrm{~s}^{-1}$ (Table 1). Synechococcus abundance in mucus strings ranged from $8.8 \times 10^{4}$ to $4.6 \times 10^{6}$ cells $\mathrm{ml}^{-1}$ and was found to be significantly higher than in ambient seawater (Wilcoxon signed rank test, 2-tailed, $\mathrm{p}<0.05$ ) by statistical comparison for each experimental day. Seawater Synechococcus abundance showed significant variability $\left(1.2\right.$ to $3.1 \times 10^{4}$ cells $\mathrm{ml}^{-1}$; 1 -way ANOVA, $\mathrm{p}<0.05)$ within the seasonal fluctuation range during the study period (Fig. 4), but remained constant in the course of each sampling event (paired-samples $t$-test, 2 -tailed, p > 0.05). On average, Synechococcus abundance in mucus strings $\left(8.2 \times 10^{5}\right.$ cells ml $\left.{ }^{-1}\right)$ was 40 -fold higher than in the surrounding seawater $\left(2.1 \times 10^{4}\right.$ cells $\mathrm{ml}^{-1}$ ). In contrast to mesocosm experiments, Synechococcus abundance in seawater showed correlation to Synechococcus enrichment found in mucus strings on the respective experimental days (Spearman rankorder correlation, 2 -tailed, $\mathrm{p}<0.01$ ). As for mucus float samples in mesocosm experiments, enrichment of mucus strings by Synechococcus from ambient seawater during sample processing was regarded as negligible due to insignificant contribution to sample volume and significant differences in Synechococcus abundance (Wilcoxon signed rank test, 2-tailed, p < 0.05).

\section{DISCUSSION}

\section{Occurrence of Synechococcus within the surface mucus layer}

The interesting finding that freshly produced mucus from Fungia corals already contained background levels of synechococcoid cyanobacteria $(1.0 \pm 0.2 \times$ $10^{4}$ cells $\mathrm{ml}^{-1}$ ), may be explained by (1) introduction of coral-associated cyanobacteria or (2) entrapment of pelagic cells by the adhesive SML, as described for larger suspended particles by Wild et al. (2005b). Previous studies have determined synechococcoid cyanobacteria to be associated with corals (Rohwer et al. 


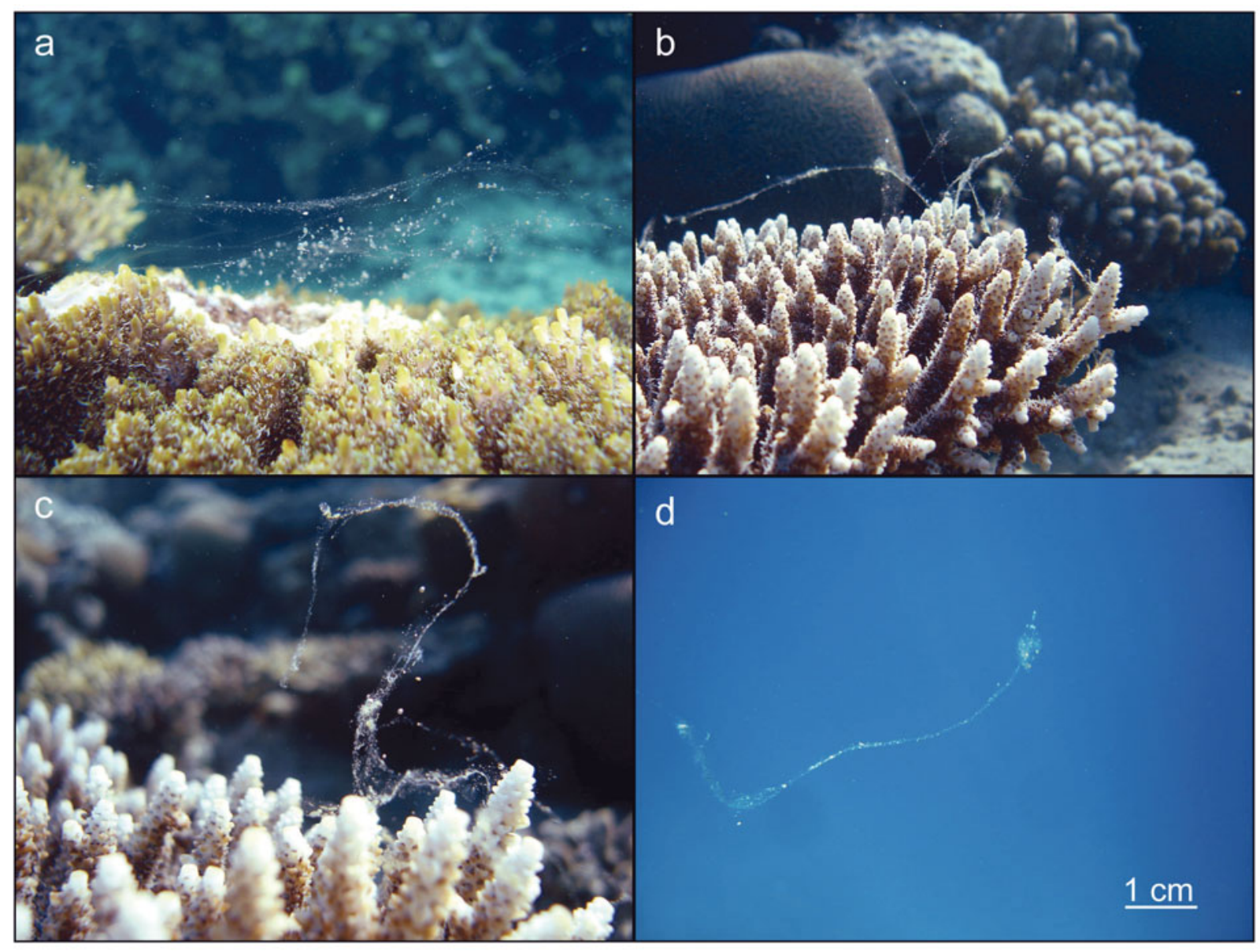

Fig. 3. Mucus aggregates produced by Acropora colonies in successive aggregation: (a) mucus web over colony surface; (b) mucus string accumulation; (c) mucus string after continued compaction; (d) mucus string drifting in water column after detachment

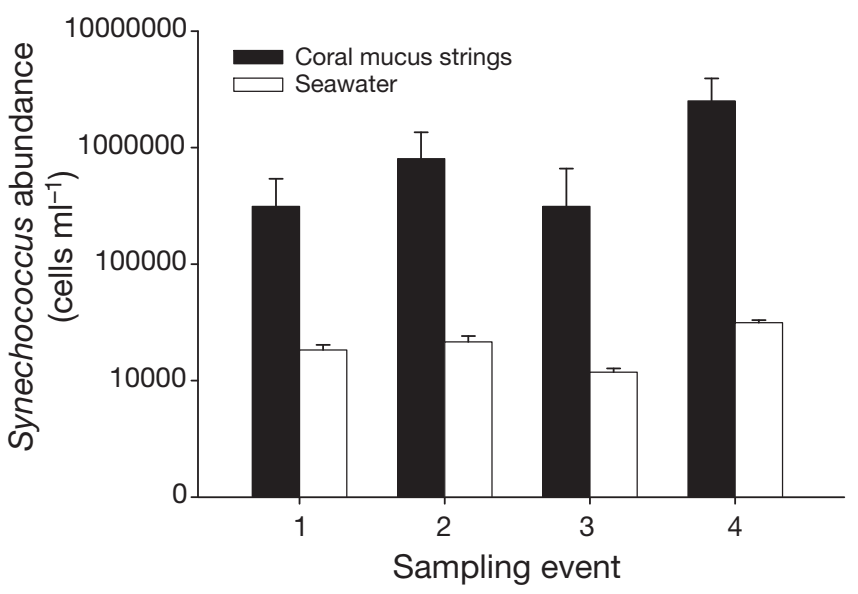

Fig. 4. Synechococcus. Abundance (mean $\pm \mathrm{SD}$ ) in coral mucus strings and local seawater at 4 in situ sampling events as described in Table 1. Coral mucus strings and seawater reference samples were collected in replicates of at least $\mathrm{n}=5$ (total: $\mathrm{n}=27$ ) and $\mathrm{n}=3$ respectively, during each sampling event
2002, Bourne \& Munn 2005, Lesser et al. 2007, Kvennefors \& Roff 2009), indicating the possible introduction of those cells into freshly produced mucus during sample collection. Continuous enrichment of pelagic Synechococcus cells via particle trapping in the attached SML remains suggestive, in particular since the mucus released during the first $30 \mathrm{~s}$ was discarded during sample collection for this study. Although the SML of corals holds a dynamic microbial community (Johnston \& Rohwer 2007), recent studies have reported on the different microbial community composition found in the SML compared to the surrounding seawater (Guppy \& Bythell 2006). Ritchie (2006) showed a distinct antibiotic activity regulated by coral mucus and mucus associated bacteria, presumably only allowing for short-term retention of entrapped pelagic cells. Furthermore, Koh (1997) observed the production of specific allelochemicals inside coral tissues targeting pelagic Synechococcus (100\% of 100 tested species), which seems to rule out a long-term association of Synechococcus with corals. 


\section{Picoplankton trapping by coral mucus and relevant factors}

The results of the present study confirm the results of previous studies (Wild et al. 2004a, Huettel et al. 2006), illustrating the efficiency of coral mucus at trapping particulate organic matter (POM) and emphasizing the validity for minute suspended particles (e.g. Synechococcus). This is a potentially important vector for pelagic picoplankton to the reef benthos. Aggregate formation processes of picoplankton-enriched mucus aggregates recorded in situ and during experimental approaches in this study closely correspond to previous observations (Johannes 1967, Coles \& Strathman 1973, Wild et al. 2004a, 2005b, Huettel et al. 2006), indicating uniformity among different reef types and oceanic regions. In rotated chamber incubations, simulation of in situ current velocity by constant rotation created coral mucus aggregates comparable in size, shape and texture to mucus strings sampled in situ at the study location. This demonstrates the applicability of the rotated chamber technique for investigations on coral mucus trapping and aggregation properties under laboratory conditions (Shanks \& Edmondson 1989). The added coral mucus trapped up to $43 \%$ of the initial Synechococcus cell content within $1 \mathrm{~h}$ of chamber rotation, thereby showing coral mucus to be an efficient scavenger for picoplankton cells and exceeding trapping efficiency for picoplankton-sized particles previously described for mucus web-feeding pteropods (Noji et al. 1997).

Relevant factors defining the extent of picoplankton enrichment in mucus aggregates appear to be current velocity, time of exposure and cell abundance, which likewise control attachment probability of larger POM (Alldredge \& McGillivary 1991). Dependency on water movement is displayed by the comparably low clearance rates in stagnant incubation chambers (C5), presumably mainly caused by grazers such as copepods and protozoa (Koehl \& Strickler 1981, Caron et al. 1991). Slight differences observed in clearance of C5 between Expts I and II likely indicate the variability of picoplankton predator abundances in seawater samples at the respective days of experiments. Water movement as a relevant factor for intensified clearance by mucus aggregates is additionally promoted by elevated clearance rates found in C4 of Expt I (increased rotation velocity) in comparison to Expts II and III. The influence of different exposure periods (60 and $8 \mathrm{~min}$ exposure, respectively) is highlighted by the elevated Synechococcus trapping rates per volume of fresh mucus in rotated chamber incubations $(2.3 \pm 1.8 \times$ $10^{3}$ cells $\mathrm{ml}^{-1}$ fresh mucus $\mathrm{min}^{-1}$ ) compared to mesocosm experiments $\left(0.3 \pm 0.2 \times 10^{3}\right)$. However, this comparison may be falsified by the disputable use of a dead Fungia skeleton for the determination of compaction factors during mesocosm experiments, possibly leading to an underestimation of the respective Synechococcus trapping rates. The significant difference of Synechococcus enrichment in mucus aggregates from in situ samplings and mesocosm experiments (Wilcoxon signed rank test, 2-tailed, p < 0.001) (Fig. 5) may also be explained by prolonged exposure of coral-attached in situ mucus webs and strings before initial string observation. However, higher Synechococcus abundances of seawater and mucus aggregates in situ compared to mesocosm experiments (MannWhitney $U$-test, 2-tailed, p < 0.01, cf. Figs. $2 \& 3$ ), and correlation of in situ mucus string enrichment to seawater abundance may suggest ambient cell abundance as an additional influencing factor. This is supported by clearance rates in rotated chamber incubations, where increased Synechococcus abundance resulted in a higher removal concerning cell numbers.

\section{Coral mucus as a carrier for picoplankton from the pelagic to the benthic reef environment}

Organic aggregates represent important hot spots for the transfer of particulate material in aquatic ecosystems (Simon et al. 2002). Particle trapping by organic aggregates and successive enrichment of suspended matter serves as a vector in the energy transport to higher trophic levels, thereby enhancing access to otherwise elusive picoplankton biomass (Ling \& Alldredge 2003). In Red Sea waters, planktonic chl a and primary production are dominated by picoplanktonic cyanobacteria (Pillen \& Moigis, cited in Lenz et al. 1988). Efficient picoplankton trapping by coral mucus and subsequent formation of enriched mucus aggre-

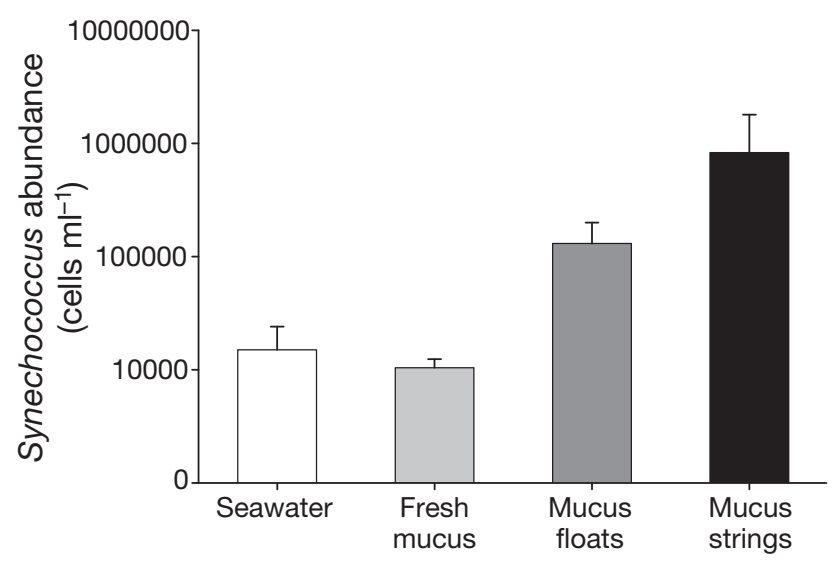

Fig. 5. Synechococcus. Abundance (mean $\pm \mathrm{SD}$ ) in seawater, freshly released coral mucus, coral mucus floats, and coral mucus strings investigated in this study. Seawater values are average values from mesocosm experiments and in situ samplings 
gates, as demonstrated by the present study, may provide reef-dwelling organisms enhanced access to planktonic biomass by particle enlargement. In the pelagic realm, entrapment of picoplankton in mucus aggregates may add to the nutrition of mucus-feeding zooplankton (Richman et al. 1975, Gottfried \& Roman 1983) and fish (Benson \& Muscatine 1974), while subsequent sedimentation of picoplankton-enriched mucus aggregates to the reef benthos implies a potential trophodynamic link in reef pelagic-benthic coupling. Integration of picoplankton into the spectrum of suspended particulates trapped by coral mucus may, in addition to the reported significant nutritious value of the mucus itself (Ducklow \& Mitchell 1979, Wild et al. 2004b), provide relevant biomass input to pelagic and benthic microbial degradation. Entrapment of picoplankton in coral mucus helps explain the substantial removal of picoplankton over reef communities described by previous studies (Ayukai 1995, Ribes et al. 2003, Houlbrèque et al. 2006). This represents a plausible mechanistic explanation for the proposed uptake of picoplankton by the benthos via picoplankton enrichment in seizable mucus aggregates. The capture and consumption of picoplankton-enriched mucus aggregates may thus be of nutritional value for a wide variety of benthic reef taxa (e.g. soft corals, gorgonians and sponges). In particular, passive suspension feeders that depend on ambient supply with seizable particulate food items may benefit from this enhanced availability of planktonic biomass, as they are not known to possess anatomical or physiological adaptations for the bulk capture of picoplankton. For instance, the pinnules on the tentacles of the azooxanthellate soft coral Dendronephthya spp. are too widely spaced (60 to $80 \mu m_{i}$ Fabricius et al. 1995) to allow for an effective capture of minute picoplankton cells. Remarkably, Fabricius et al. (1995) reported the detection of picoplankton cells in the gastrovascular cavities of Dendronephthya hemprichi polyps, raising the question of how these minute particles are intercepted by the tentacles and transferred to the interior of the polyps. As conceivable for Dendronephthya spp., which still presents unresolved gaps within its metabolic energy budget (Widdig \& Schlichter 2001), facilitated capture of larger picoplankton-enriched mucus aggregates may also provide an important trophic source for other passive suspension-feeding reef organisms.

\section{CONCLUSIONS}

This study demonstrates the efficient trapping and enrichment abilities of scleractinian coral mucus for picoplankton-sized organisms using the cyanobacterium Synechococcus as a model organism. Syne- chococcus abundance in seawater measured here (1.2 to $3.1 \times 10^{4}$ cells ml $^{-1}$ ) was in the range of results from previous studies $\left(2.5 \pm 2.1 \times 10^{4}\right.$ cells $\mathrm{ml}^{-1}$; Gradinger et al. 1992) and indicates the dominance of unicellular cyanobacteria within Red Sea picoplankton biomass. However, as another important picoplankton group, heterotrophic bacteria have been found in significantly higher cell abundances (5.2 to $8.8 \times 10^{5}$ cells $\mathrm{ml}^{-1}$; Weisse 1989, Grossart \& Simon 2002), although contributing a disproportionately smaller fraction to overall picoplankton biomass, at least in terms of nitrogen (Ribes et al. 2003). An assumed similar mucus trapping efficiency for all groups within the picoplankton community may emphasize the role of coral mucus as a carrier of trapped picoplankton biomass to the benthic communities.

Acknowledgements. The authors are grateful to M. Khalaf and the late Y. Ahmed (Marine Science Station, Aqaba, Jordan), A. Boetius (MPI for Marine Microbiology, Bremen, Germany), U. Fischer (UFT, Bremen, Germany) and S. Luna (NAZCA, Quito, Ecuador) for technical and logistical support. This study was supported by DFG grant Wi 2677/2-1 to C.W. and the German ministry for Education and Science (BMBF) grant 03F0356A to C.R.

\section{LITERATURE CITED}

Alldredge A, McGillivary P (1991) The attachment probabilities of marine snow and their implications for particle coagulation in the ocean. Deep-Sea Res 38:431-443

Ayukai T (1995) Retention of phytoplankton and planktonic microbes on coral reefs within the Great Barrier Reef, Australia. Coral Reefs 14:141-147

Benson A, Muscatine L (1974) Wax in coral mucus: Energy transfer from corals to reef fishes. Limnol Oceanogr 19:810-814

Booth BC (1987) The use of autofluorescence for analysing oceanic phytoplankton communities. Bot Mar 30:101-108

Bourne DG, Munn CB (2005) Diversity of bacteria associated with the coral Pocillopora damicornis from the Great Barrier Reef. Environ Microbiol 7:1162-1174

> Caron DA, Lim EL, Miceli G, Waterbury JB, Valois FW (1991) Grazing and utilization of chroococcoid cyanobacteria and heterotrophic bacteria by protozoa in laboratory cultures and a coastal community. Mar Ecol Prog Ser 76:205-217

Coles S, Strathman R (1973) Observations on coral mucus 'flocs' and their potential trophic significance. Limnol Oceanogr 18:673-678

Crumpton WG (1987) A simple and reliable method for making permanent mounts of phytoplankton for light and fluorescence microscopy. Limnol Oceanogr 32:1154-1159

Ducklow HW (1990) Coral reefs. In: Dubinsky Z (ed) Ecosystems of the world. Elsevier, Amsterdam, p 265-289

Ducklow HW, Mitchell R (1979) Bacterial populations and adaptations in the mucus layers on living corals. Limnol Oceanogr 24:715-725

Fabricius KE, Genin A, Benayahu Y (1995) Flow-dependent herbivory and growth in zooxanthellae-free soft corals. Limnol Oceanogr 40:1290-1301

Fuller NJ, Marie D, Partensky F, Vaulot D, Post AF, Scanlan DJ (2003) Clade-specific 16S ribosomal DNA oligonu- 
cleotides reveal the predominance of a single marine Synechococcus clade throughout a stratified water column in the Red Sea. Appl Environ Microbiol 69:2430-2443

> Goldberg WM (2002) Feeding behaviour, epidermal structure and mucus cytochemistry of the scleractinian Mycetophyllis reesi, a coral without tentacles. Tissue Cell 34:232-245

> Gottfried M, Roman MR (1983) Ingestion and incorporation of coral mucus detritus by reef zooplankton. Mar Biol 72: 211-218

Gradinger R, Weiss T, Pillen T (1992) Significance of picocyanobacteria in the Red Sea and the Gulf of Aden. Bot Mar 35:245-250

Grossart HP, Simon M (2002) Bacterioplankton dynamics in the Gulf of Aqaba and the northern Red Sea during early spring. Mar Ecol Prog Ser 239:263-276

> Guppy R, Bythell JC (2006) Environmental effects on bacterial diversity in the surface mucus layer of the reef coral Montastraea faveolata. Mar Ecol Prog Ser 328:133-142

Houlbrèque F, Tambutté E, Richard C, Ferrier-Pagès C (2004) Importance of a micro-diet for scleractinian corals. Mar Ecol Prog Ser 282:151-160

Houlbrèque F, Delesalle B, Blanchot J, Montel Y, FerrierPagès $C$ (2006) Picoplankton removal by the coral reef community of La Prévoyante, Mayotte Island. Aquat Microb Ecol 44:59-70

Huettel M, Wild C, Gonelli S (2006) Mucus trap in coral reefs: formation and temporal evolution of particle aggregates caused by coral mucus. Mar Ecol Prog Ser 307:69-84

Johannes R (1967) Ecology of organic aggregates in the vicinity of a coral reef. Limnol Oceanogr 7:189-195

Johnson PW, Sieburth JM (1979) Chroococcoid cyanobacteria in the sea: A ubiquitous and diverse phototrophic biomass. Limnol Oceanogr 24:928-935

Johnston IS, Rohwer F (2007) Microbial landscapes on the outer tissue surfaces of the reef-building coral Porites compressa. Coral Reefs 26:375-383

Kappner I, Al-Moghrabi SM, Richter C (2000) Mucus-net feeding by the vermetid gastropod Dendropoma maxima in coral reefs. Mar Ecol Prog Ser 204:309-313

Koblizek M, Komenda J, Masojidek J, Pechar L (2000) Cell aggregation of the cyanobacterium Synechococcus elongatus: role of the electron transport chain. J Phycol 36: 662-668

Koehl MAR, Strickler JR (1981) Copepod feeding currents: food capture at low Reynolds number. Limnol Oceanogr 26:1062-1073

Koh EGL (1997) Do scleractinian corals engage in chemical warfare against microbes? J Chem Ecol 23:379-398

Kvennefors ECE, Roff G (2009) Evidence of cyanobacterialike endosymbionts in Acroporid corals from the Great Barrier Reef. Coral Reefs 28:547

Lenz J, Schneider G, El Hag AGD, Gradinger R and others (1988) Planktological data from the central Red Sea and the Gulf of Aden. Ber Inst Meereskd Christian-AlbrechtsUniv Kiel 180:1-200

Lesser MP, Falcón LI, Rodríguez-Román A, Enríquez S, Hoegh-Guldberg O, Iglesias-Prieto R (2007) Nitrogen fixation by symbiotic cyanobacteria provides a source of nitrogen for the scleractinian coral Montastraea cavernosa. Mar Ecol Prog Ser 346:143-152

Li WKW, Wood AM (1988) Vertical distribution of North Atlantic ultraphytoplankton: analysis by flow cytometry and epifluorescence microscopy. Deep-Sea Res 35: 1615-1638

Li WKW, Rao DVS, Harrison WG, Smith JC, Cullen JJ, Irwin B, Platt T (1983) Autotrophic picoplankton in the tropical ocean. Science 219:292-295
Lindell D, Post AF (1995) Ultraphytoplankton succession is triggered by deep winter mixing in the Gulf of Aqaba (Eilat), Red Sea. Limnol Oceanogr 40:1130-1141

Ling SC, Alldredge AL (2003) Does the marine copepod Calanus pacificus consume transparent exopolymer particles (TEP)? J Plankton Res 25:507-515

> Loya Y (1976) Recolonization of Red Sea corals affected by natural catastrophes and man-made perturbations. Ecology 57:278-289

Marie D, Partensky F, Simon N, Guillou L, Vaulot D (2000) Flow cytometry analysis of marine picoplankton. In: Diamond RA, DeMaggio S (eds) In living color: protocols in flow cytometry and cell sorting. Springer Verlag, Heidelberg, p 421-454

> Naumann MS, Niggl W, Laforsch C, Glaser C, Wild C (2009) Coral surface area quantification-evaluation of established methods by comparison with computer tomography. Coral Reefs 28:109-117

Noji TT, Bathmann UV, Bodungen BV, Voss M and others (1997) Clearance of picoplankton-sized particles and formation of rapidly sinking aggregates by the pteropod, Limacina retroversa. J Plankton Res 19:863-875

Owens NJP, Burkill P, Mantoura R, Woodward E and others (1993) Size-fractionated primary production and nitrogen assimilation in the Northwestern Indian Ocean. Deep-Sea Res 240:697-709

Passow U, Alldredge AL (1995) A dye-binding assay for the spectrophotometric measurement of transparent exopolymer particles (TEP). Limnol Oceanogr 40:1326-1335

> Pedros-Alio C, Mas J, Gasol JM, Guererro R (1989) Sinking speeds of free-living phototrophic bacteria determined with covered and uncovered sediment traps. J Plankton Res 11:887-905

Ribes M, Coma R, Atkinson MJ, Kinzie RA III (2003) Particle removal by coral reef communities: picoplankton is a major source of nitrogen. Mar Ecol Prog Ser 257:13-23

Richardson TL, Jackson GA (2007) Small phytoplankton and carbon export from the surface ocean. Science 315: $838-840$

Richman S, Loya Y, Slobodkin LB (1975) The rate of mucus production by corals and its assimilation by the coral reef copepod Acartia negligens. Limnol Oceanogr 20:918-923

> Richter C, Wunsch M, Rasheed M, Kötter I, Badran MI (2001) Endoscopic exploration of Red Sea coral reefs reveals dense populations of cavity-dwelling sponges. Nature 413:726-730

Ritchie KB (2006) Regulation of microbial populations by coral surface mucus and mucus-associated bacteria. Mar Ecol Prog Ser 322:1-14

Rohwer F, Seguritan V, Azam F, Knowlton N (2002) Diversity and distribution of coral-associated bacteria. Mar Ecol Prog Ser 243:1-10

Shanks A, Edmondson EW (1989) Laboratory-made artificial marine snow: a biological model of the real thing. Mar Biol 101:463-470

Sieburth JM, Smetacek V, Lenz J (1978) Pelagic ecosystem structure: Heterotrophic compartments of the plankton and their relationship to plankton size fractions. Limnol Oceanogr 23:1256-1263

Simon M, Grossart HP, Schweitzer B, Ploug H (2002) Microbial ecology of organic aggregates in aquatic ecosystems. Aquat Microb Ecol 28:175-211

Tremblay JE, Legendre L (1994) A model for the size-fractionated biomass and production of marine phytoplankton. Limnol Oceanogr 39:2004-2014

Waite AM, Safi KA, Hall JA, Nodder SD (2000) Mass sedimentation of picoplankton embedded in organic aggre- 
gates. Limnol Oceanogr 45:87-97

Weisse T (1989) The microbial loop in the Res Sea: dynamics of pelagic bacteria and heterotrophic nanoflagellates. Mar Ecol Prog Ser 55:241-250

Widdig A, Schlichter D (2001) Phytoplankton: a significant trophic source for soft corals? Helgol Mar Res 55:198-211

- Wild C, Huettel M, Klueter A, Kremb S, Rasheed M, Joergensen BB (2004a) Coral mucus functions as an energy carrier and particle trap in the reef ecosystem. Nature 428:66-70

Wild C, Rasheed M, Werner U, Franke U, Johnstone R, Huet-

Editorial responsibility: Matthias Seaman,

Oldendorf/Luhe, Germany tel M (2004b) Degradation and mineralization of coral mucus in reef environments. Mar Ecol Prog Ser 267: 159-171

> Wild C, Woyt H, Huettel M (2005a) Influence of coral mucus on nutrient fluxes in carbonate sands. Mar Ecol Prog Ser 287:87-98

> Wild C, Rasheed M, Jantzen C, Cook P, Struck U, Boetius A (2005b) Benthic metabolism and degradation of natural particulate organic matter in carbonate and silicate reef sands of the northern Red Sea. Mar Ecol Prog Ser 298:69-87

Submitted: January 12, 2009; Accepted: April 21, 2009

Proofs received from author(s): June 16, 2009 